\title{
Essential oil from Xylopia frutescens Aubl. reduces cytosolic calcium levels on guinea pig ileum: mechanism underlying its spasmolytic potential
}

\author{
lara Leão Luna de Souza ${ }^{1}$, Ana Carolina de Carvalho Correia ${ }^{2}$, Layanne Cabral da Cunha Araujo ${ }^{3}$, \\ Luiz Henrique César Vasconcelos ${ }^{1}$, Maria da Conceição Correia Silva', Vicente Carlos de Oliveira Costa ${ }^{4}$, \\ Josean Fechine Tavares ${ }^{1,4}$, Edgar Julian Paredes-Gamero ${ }^{5}$, Fabiana de Andrade Cavalcante ${ }^{1,4,6^{*}}$ \\ and Bagnólia Araújo da Silva ${ }^{1,4}$
}

\begin{abstract}
Background: Xylopia frutescens Aubl. (embira, semente-de-embira or embira-vermelha), is used in folk medicine as antidiarrheal. The essential oil from its leaves (XF-EO) has been found to cause smooth muscle relaxation. Thus, the aim of this study was to investigate the spasmolytic action by which XF-EO acts on guinea pig ileum.

Methods: The components of the XF-EO were identified by gas chromatography-mass spectrometry. Segments of guinea pig ileum were suspended in organ bath containing modified Krebs solution at $37^{\circ} \mathrm{C}$, bubbled with carbogen mixture under a resting tension of $1 \mathrm{~g}$. Isotonic contractions were registered using kymographs and isometric contractions using force transducer coupled to an amplifier and computer. Fluorescence measurements were obtained with a microplate reader using Fluo-4.

Results: Forty-three constituents were identified in XF-EO, mostly mono- and sesquiterpenes. XF-EO has been found to cause relaxation on guinea pig ileum. The essential oil inhibited in a concentration-dependent manner both CCh- and histamine-induced phasic contractions, being more potent on histamine-induced contractions as well as antagonized histamine-induced cumulative contractions in a non-competitive antagonism profile. XF-EO relaxed in a concentration-dependent manner the ileum pre-contracted with $\mathrm{KCl}$ and histamine. Since the potency was smaller in organ pre-contracted with $\mathrm{KCl}$, it was hypothesized that XF-OE would be acting as a $\mathrm{K}^{+}$channel positive modulator. In the presence of $\mathrm{CsCl}$ (non-selective $\mathrm{K}^{+}$channel blocker), the relaxant potency of XF-OE was not altered, indicating a non-participation of these channels. Moreover, XF-EO inhibited $\mathrm{CaCl}_{2}$-induced cumulative contractions in a depolarizing medium nominally without $\mathrm{Ca}^{2+}$ and relaxed the ileum pre-contracted with S-(-)-Bay K8644 in a concentration-dependent manner, thus, was confirmed the inhibition of $\mathrm{Ca}^{2+}$ influx through $\mathrm{Ca}_{\mathrm{v}} 1$ by XF-EO. In cellular experiments, the viability of longitudinal layer myocytes from guinea pig ileum was not altered in the presence of XF-OE and the Fluo-4-associated fluorescence intensity in these intestinal myocytes stimulated by histamine was reduced by the essential oil, indicating a $\left[\mathrm{Ca}^{2+}\right]_{\mathrm{c}}$ reduction.
\end{abstract}

Conclusion: Spasmolytic action mechanism of XF-EO on guinea pig ileum can involve histaminergic receptor antagonism and $\mathrm{Ca}^{2+}$ influx blockade, which results in $\left[\mathrm{Ca}^{2+}\right]_{\mathrm{c}}$ reduction leading to smooth muscle relaxation.

Keywords: Xylopia frutescens, Essential oil, Spasmolytic action, Guinea pig ileum, Calcium

\footnotetext{
* Correspondence: fabianacavalcante@ltf.ufpb.br

${ }^{1}$ Centro de Ciências da Saúde/Universidade Federal da Paraíba, João Pessoa,

Paraíba, Brazil

${ }^{4}$ Instituto de Pesquisa em Fármacos e Medicamentos/Universidade Federal da

Paraíba, João Pessoa, Paraíba, Brazil

Full list of author information is available at the end of the article
} 


\section{Background}

Diarrhea is characterized by change in bowel movements with symptoms of increment in water content, volume and frequency of stool [1]. It is the second leading cause of death in children under five years old, and it is responsible for around 760.000 children deaths every year [2]. For this reason, international organizations have encouraged studies pertaining to treatment and prevention of diarrheal diseases using traditional medicinal practices [3].

Xylopia frutecens Aubl. is a tree commonly known in Brazil as "embira", "semente-de-embira" and "embiravermelha" [4] and belongs to the Annonaceae family. In folk medicine, its seeds are used to rheumatism and inflammation treatment, to improve digestion and as antidiarrheal [5-7].

Chemical studies showed that kaurenoic acid, a kaurene diterpene abundant in the seeds of this species presents anti-inflammatory [7], analgesic [8], diuretic and vasorelaxant activities [9]. In addition, pharmacological investigations have demonstrated antiviral [10], antifungal [11], tripanossomicide [12], antitumor [13] and spasmolytic activity [14] for $X$. frutescens. Despite the common use of this plant in popular medicine, there is a lack of information to support its effect on intestinal smooth muscle. Hence, the present study aimed to evaluate the spasmolytic activity and possible mechanism of action of the essential oil from $X$. frutescens (XF-EO) on guinea pig ileum, to ascertain ethnopharmacological claims.

\section{Methods}

\section{Plant material and essential oil preparation}

The plant material of Xylopia frutescens Aubl. was collected in April 2010 in João Pessoa municipality, State of Paraíba, Brazil. The material was identified by Maria de Fátima Agra (PhD) of the Centro de Biotecnologia (CBiotec) of Universidade Federal da Paraíba (UFPB), and the voucher specimen (Agra 7249) is deposited at the Prof. Lauro Pires Xavier (JPB) Herbarium/UFPB.

Fresh leaves from Xylopia frutescens were ground and submitted to hydrodistillation using a Clevenger-type apparatus (1500 g, $\left.6 \mathrm{~h}, 40{ }^{\circ} \mathrm{C}\right)$. The oil was dried over anhydrous sodium sulfate and its percentage content was calculated on basis of the plant dry weight. The essential oil was used for the spasmolytic activity studies.

\section{Identification of essential oil components}

The analysis of the essential oil was carried out on a SHIMADZU gas chromatography-mass spectrometry (GCMS) instrument under the following conditions: DB-5 ms (30 $\mathrm{m} \times 0.25 \mathrm{~mm}$ d.i., $0.25 \mu \mathrm{M}$ film thickness), fused-silica capillary column, programmed temperature of $60-240{ }^{\circ} \mathrm{C}$ $\left(3{ }^{\circ} \mathrm{C} / \mathrm{min}\right)$, injector temperature at $220{ }^{\circ} \mathrm{C}$, helium carrier gas adjusted to a linear velocity of $32 \mathrm{~cm} / \mathrm{s}$ (measured at $\left.100{ }^{\circ} \mathrm{C}\right)$, splitless injection $(2 \mu \mathrm{L} \mathrm{1:1000}$ hexane solution), split flow adjusted to yield a 20:1 ratio, septum sweep constant at $10 \mathrm{~mL} / \mathrm{min}$, EIMS electron energy of $70 \mathrm{eV}$, ion source and connections at $200{ }^{\circ} \mathrm{C}$. The quantitative data for the volatile constituents were obtained by peakarea normalization using a FOCUS GC/ flame ionization detector (FID), operated under GC-MS similar conditions except for the carrier gas, which was nitrogen. The retention index was calculated for all the volatile constituents using an n-alkane (C8-C20, Sigma-Aldrich, Brazil) homologous series.

Individual components were identified by comparison of both mass spectrum and GC retention data with previously analyzed authentic compounds stored in our private library, as well as with the aid of commercial libraries containing mass spectra, and retention indices of volatile compounds commonly found in essential oils $[15,16]$.

\section{Chemicals}

The following reference chemicals were obtained from the sources specified: histamine dihydrochloride, carbachol (CCh) (Merck, EUA), Cremophor EL ${ }^{\oplus}, \mathrm{S}-(-)$-Bay K8644, cesium chloride $(\mathrm{CsCl})$, EDTA, HEPES, methylthiotetrazole (MTT), dimethyl sulfoxide (DMSO), penicillinstreptomycin (Sigma-Aldrich, Brazil), ethanol PA (Reagen, Brazil), dulbecco's modified eagle medium (DMEM), bovine fetal serum, L-glutamine and trypsin/EDTA solution (1:250) (Cultilab, Brazil) and Flou-4 NW dye mix (Invitrogen, EUA).

The following chemicals were used to make the physiological salt solutions: glucose, magnesium sulphate, calcium chloride (Vetec, Brazil), sodium bicarbonate (Fmaia, Brazil), sodium chloride, potassium chloride (Química Moderna, Brazil), monosodium phosphate-1-hydrate, sodium hydroxide and hydrochloric acid (Nuclear, Brazil)

All chemicals used were of the highest purity grade available. Stock solutions of all the chemicals were made in distilled water and the dilutions were made fresh on the day of the experiment.

Carbogen mixture $\left(95 \% \mathrm{O}_{2}\right.$ and $\left.5 \% \mathrm{CO}_{2}\right)$ was obtained from White Martins (Brazil).

\section{Animals and organ manipulation}

Adult guinea pigs (Cavia porcellus) of both sexes weighing 300-500 g, obtained from Bioterium Prof. Thomas George of UFPB, were used in this study. Animals had full access to food (Labina ${ }^{\circ}$ ) and water, were kept in rooms at $21 \pm 1{ }^{\circ} \mathrm{C}$ and submitted to a $12 \mathrm{~h}$ light-dark cycle (lights on 06 to $18 \mathrm{~h}$ ). Eighteen hours before experiments, food was withheld and free access to water was maintained. All experimental procedures were performed in accordance with guidelines for the ethical use of animals in applied etiology studies [17] and approved by UFPB Ethic Committee on Animal Use (protocol/CEUA no. 0611/13). 
Animals were euthanized by cervical dislocation. An ileum segment (approximately $15 \mathrm{~cm}$ ) was removed, cleaned of adhering fat and connective tissue, and suspended in organ baths containing modified Krebs solution [18] at $37{ }^{\circ} \mathrm{C}$ and bubbled with carbogen mixture. Solution $\mathrm{pH}$ was adjusted to 7.4 with $\mathrm{HCl}$ or $\mathrm{NaOH} 1 \mathrm{~N}$, as necessary. The resting tension was fixed at $1 \mathrm{~g}$ and the preparation was allowed to stabilization for $30 \mathrm{~min}$.

To register isotonic contractions, organs were suspended by cotton yarn in organ baths $(5 \mathrm{~mL})$ and recorded on smoked drum through levers coupled to kymographs (DTF, Brazil). To register isometric contractions, organs were suspended in steel rods in organ baths $(6 \mathrm{~mL})$, connected to a force transducer (TIM 05), attached to an amplifier (AECAD04F) and connected to an A/D converter into a $\mathrm{PC}$ running $\mathrm{AQCAD}^{\circledR}$ software (São Paulo, Brazil).

\section{Cell culture}

The guinea pig ileum was collected and the longitudinal smooth muscle layer was carefully stripped off. The pieces removed were placed in warmed physiological solution and the organ was successively washed with solution without $\mathrm{Ca}^{2+}$ and enriched with penicillin. Afterwards, tissue samples were transferred to culture bottles and was added DMEM culture medium supplemented with glutamine and $10 \%$ bovine fetal serum, then, the bottles were stored in $\mathrm{CO}_{2}$ incubator [19]. After $24 \mathrm{~h}$, the culture medium was added to the bottles and $48 \mathrm{~h}$ later the bottles were washed with PBS and the culture medium was replaced until the bottles become confluent. In this case, the medium was removed, added trypsin/EDTA (1:2500) for $2 \mathrm{~min}$ in incubator and the cells were resuspended in culture medium and centrifuged $(500 \times \mathrm{g})$ for $5 \mathrm{~min}$. The supernatant was discarded and the pellets formed were used in the experiments.

\section{Spasmolytic analysis \\ Effect of XF-EO on carbachol- and histamine-induced phasic contractions}

Two similar concentration-response curves were obtained with $\mathrm{CCh}\left(10^{-6} \mathrm{M}\right)$ or histamine $\left(10^{-6} \mathrm{M}\right)$. Then, XF-EO effects were determined by pre-incubating the ileum strips for $15 \mathrm{~min}$ with a single concentration of the essential oil in independent experiments before adding CCh or histamine. The inhibitory effect exerted by the essential oil was evaluated based on $\mathrm{IC}_{50}$ analysis, which is defined as the molar concentration values of an antagonist which produces $50 \%$ of its maximum inhibitory response, and maximum effect $\left(E_{\max }\right)$, assessed through concentration-response curves in both absence (control) and presence of XF-EO [20].

\section{Effect of XF-EO on histamine-induced cumulative contractions}

Two similar cumulative concentration-response curves for histamine $\left(10^{-9}-10^{-4} \mathrm{M}\right)$ were induced (control) and the tissue was exposed to different concentrations of XF-EO for $15 \mathrm{~min}$, followed by a new histamine cumulative curve. The maximal contraction obtained in the absence of XF-EO was considered to be $100 \%$ (control) and all contractions were assessed referring to it. The inhibitory effect exerted by the essential oil was evaluated based on analysis of $\mathrm{EC}_{50}$ values, which is defined as the molar concentration values of an agonist which produces $50 \%$ of its maximum effective response, and $E_{\max }$, assessed through concentration-response curves in both absence (control) and presence of XF-EO [21].

\section{Effect of XF-EO on $\mathrm{KCl}$-induced tonic contraction or histamine-induced tonic contractions in both absence and presence of non-selective potassium channel blocker}

A contraction was induced with $\mathrm{KCl}(40 \mathrm{mM})$ or histamine $\left(10^{-6} \mathrm{M}\right)$. During the tonic phase, XF-EO was cumulatively added as an attempt to obtain concentrationrelaxation curves in different preparations. Then, the histamine-induced tonic contraction was washed out and $\mathrm{CsCl}(5 \mathrm{mM})$, a non-selective $\mathrm{K}^{+}$channel blocker $[22,23]$, was added for $20 \mathrm{~min}$. Then, another tonic contraction was elicited in the presence of the blocker and the essential oil was cumulatively added. The relaxant potency of XF$\mathrm{EO}$ was evaluated by comparing $\mathrm{EC}_{50}$ values in both absence (control) and presence of $\mathrm{CsCl}$.

\section{Effect of XF-EO on $\mathrm{Ca}^{2+}$ influx}

After stabilization period, the modified Krebs solution was replaced by a depolarizing modified Krebs solution nominally without $\mathrm{Ca}^{2+}(\mathrm{KCl}, 4 \mathrm{mM}$ was increased to $70 \mathrm{mM}$ with equimolar exchange for $\mathrm{NaCl}$ ). After $45 \mathrm{~min}$, two concentration-response curves to $\mathrm{CaCl}_{2}\left(10^{-5}\right.$ to $\left.10^{-1} \mathrm{M}\right)$ were constructed (control) and the tissue was exposed to different concentrations of XF-EO for $15 \mathrm{~min}$, followed by a new concentration-response curve to $\mathrm{CaCl}_{2}$. The maximal contraction obtained in the absence of XF-OE was considered to be $100 \%$ (control) and all contractions were assessed referring to it. The inhibitory effect exerted by the essential oil was evaluated based on analysis of $\mathrm{EC}_{50}$ and $\mathrm{E}_{\max }$ values, assessed through concentration-response curves in both absence (control) and presence of XF-EO [24].

In other experiments, the ileum was partially depolarized with $\mathrm{KCl}(15 \mathrm{mM})$ for $10 \mathrm{~min}$ [25], then, was induced a contraction with S-(-)-Bay K8644 (3 x 10-7 M), a selective voltage-dependent calcium channel $\left(\mathrm{Ca}_{\mathrm{v}}\right)$ agonist to L-type or $\mathrm{Ca}_{V} 1$ [26]. During the tonic contraction, the essential oil was added cumulatively in different preparations, in order to obtain a relaxation curve. The 
relaxation was expressed as the reversal percentage of initial contraction elicited by the S-(-)-Bay K8644 and evaluated by comparing $\mathrm{EC}_{50}$ values in both absence (control) and presence of the $\mathrm{Ca}_{\mathrm{V}} 1$ agonist.

\section{Effect of XF-EO on myocytes from ileum longitudinal layer}

Interference of XF-EO on ileum myocytes viability Cell viability was determined using the MTT assay [27]. Briefly, ileum myocytes were seeded at the density of $70-80 \%$ confluence per well in 96-well plates for $24 \mathrm{~h}$ incubation and treated with XF-EO. After treatment, $10 \mu \mathrm{L}$ of MTT $(5 \mathrm{mg} / \mathrm{mL})$ was added and the myocytes were incubated for $6 \mathrm{~h}$ at $37{ }^{\circ} \mathrm{C}$ in $\mathrm{CO}_{2}$ incubator. The supernatant was discarded and the water-insoluble dark blue formazan crystals formed in viable cells were solubilized in DMSO. The spectrophotometric absorbance was measured at $540 \mathrm{~nm}$ using a microplate reader (FlexStation 3) and the Soft Max Pro software (Molecular Devices, USA). Triplicate experiments were performed and the absorbance from the wells of cells cultured with DMSO was taken as $100 \%$ (control) of viability value.

Effect of XF-EO on cytosolic calcium concentration of ileum myocytes The pellets were obtained as described earlier, cultured in 96-well plates (40.000 cells per well) and stabilized in incubator for $24 \mathrm{~h}$ for cell adhesion. After this process, the culture medium of each well was discarded and $50 \mu \mathrm{L}$ of Fluo-4 (Molecular Probes/Invitrogen, USA) was added and let rest for 40 min at $37^{\circ} \mathrm{C}$ in $\mathrm{CO}_{2}$ incubator [28]. After the fluorophore incorporation, the Fluo-4-associated fluorescence was quantified in a microplate reader (FlexStation 3) using the Soft Max Pro software (Molecular Devices, USA). The excitation of Fluo- 4 occurs at $490 \mathrm{~nm}$, and the light emission at $524 \mathrm{~nm}$. Records were obtained without interruption for $240 \mathrm{~s}$. The Fluo-4-associated fluorescence intensity was increased by adding histamine $\left(10^{-6} \mathrm{M}\right)$, and later, verapamil $\left(10^{-6} \mathrm{M}\right)$ (positive control), HBSS (negative control) or XF-EO were added, in different experiments, to assess the action in modify the $\left[\mathrm{Ca}^{2+}\right]_{\mathrm{c}}$. Experiments were performed in triplicate.

\section{Statistical analysis}

The values were expressed as mean and standard error of mean (S.E.M.). Differences between values were statistically compared using Student's t-test and one-way ANOVA, followed by Bonferroni's test when applicable, and were considered to differ significantly when $p<0.05$. $\mathrm{IC}_{50}$ and $\mathrm{EC}_{50}$ values were calculated with nonlinear regression [29]. All values were analyzed using GraphPad
Prism software version 5.01 (GraphPad Software Inc., San Diego CA, USA).

\section{Results}

Identification of essential oil components

Forty-three compounds of the XF-OE were identified by GC-MS, most of them being represented by monoterpenes $(18 \%)$ and sesquiterpenes $(67.5 \%)$. The major components were caryophyllene (23.91\%), $\gamma$-cadinene (12.48\%), $\beta$-ocimene (8.19\%), cadin-4-en-10-ol (5.78\%). $\delta$-cadinene $(5.7 \%)$, viridiflorol $(4.83 \%)$ and $\gamma$-elemene $(4.55 \%)$ (Table 1).

\section{Effect of XF-EO on carbachol- and histamine-induced phasic contractions}

XF-EO $(3-729 \mu \mathrm{g} / \mathrm{mL}, n=5)$ antagonized the phasic contractions induced by CCh $\left(\mathrm{IC}_{50}=74.0 \pm 8.1 \mu \mathrm{g} / \mathrm{mL}\right)$ or histamine $\left(\mathrm{IC}_{50}=38.1 \pm 2.6 \mu \mathrm{g} / \mathrm{mL}\right) \quad$ (Fig. 1) on guinea pig ileum in a concentration-dependent manner. The $E_{\max }$ values were $97.2 \pm 1.3$ and $94.6 \pm 3.0 \%$, respectively.

Table 1 Chemical composition of the essential oil obtained from the leaves of Xylopia frutescens

\begin{tabular}{ll}
\hline Substances & (Relative \%) \\
\hline Caryophyllene & 23,91 \\
y-cadinene & 12,48 \\
B-ocimene & 8,19 \\
Cadin-4-en-10-ol & 5,78 \\
Viridiflorol & 4,83 \\
y-elemene & 4,55 \\
B-elemene & 4,31 \\
a-selinene & 4,29 \\
Sphatulenol & 3,97 \\
Delta-cadinene & 3,02 \\
a-humulene & 2,48 \\
a-pinene & 2,30 \\
y-muurolene & 2,23 \\
B-selinene & 2,11 \\
a- cubebene & 1,31 \\
Germacrene A & 1,25 \\
Aromadendrene & 0,99 \\
Camphene & 0,94 \\
Mircene & 0,92 \\
Bornyl acetate & 0,34 \\
Total & 90,20 \\
\hline
\end{tabular}



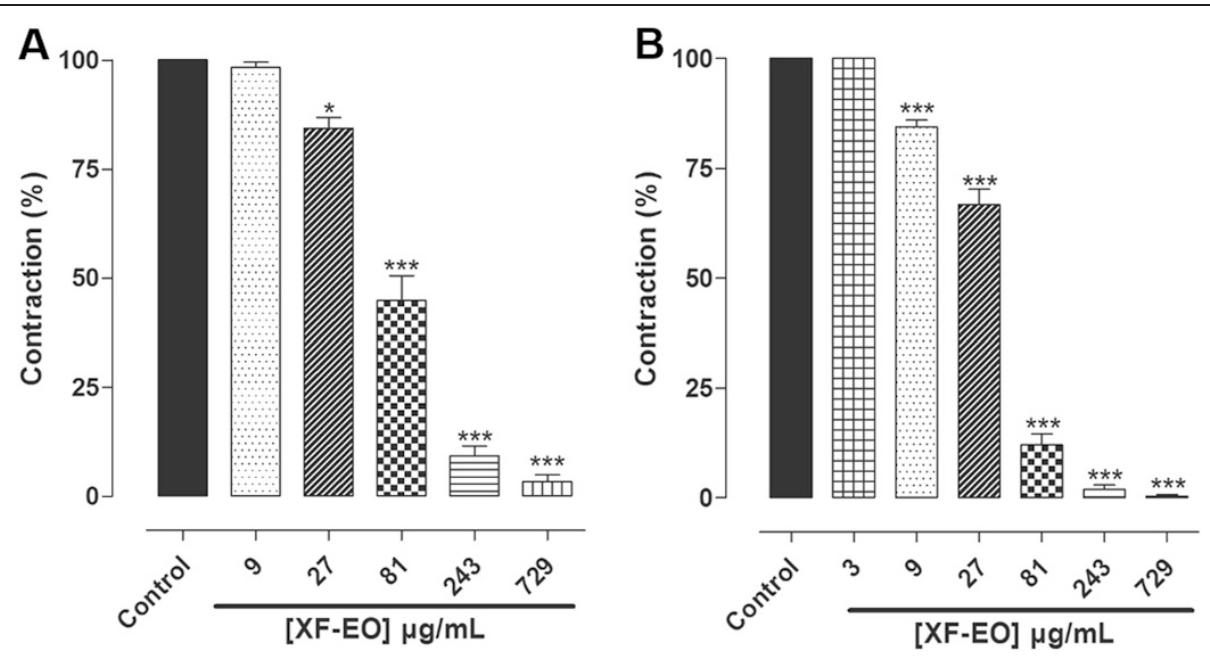

Fig. 1 Effect of XF-EO on phasic contractions induced by CCh (a) or histamine (b) on guinea pig ileum $(n=5)$. Columns and vertical bars represent mean and S.E.M, respectively. One-way ANOVA followed by Bonferroni's test, ${ }^{*} p<0.05,{ }^{* * *} p<0.001$ (control vs. XF-EO)

\section{Effect of XF-EO on histamine-induced cumulative contractions}

XF-EO (9-81 $\mu \mathrm{g} / \mathrm{mL}, n=5)$ concentration-dependently inhibited histamine-induced contractions (Fig. 2). Histamine cumulative concentration-response was non-parallelly shifted to the right and its $E_{\max }$ reduced from $100 \%$ (control) to $81.3 \pm 2.9,67.9 \pm 3.5,50.0 \pm 4.7$ and $0 \%$. The $\mathrm{EC}_{50}$ was attenuated from $2.3 \pm 0.3 \times 10^{-7} \mathrm{M}$

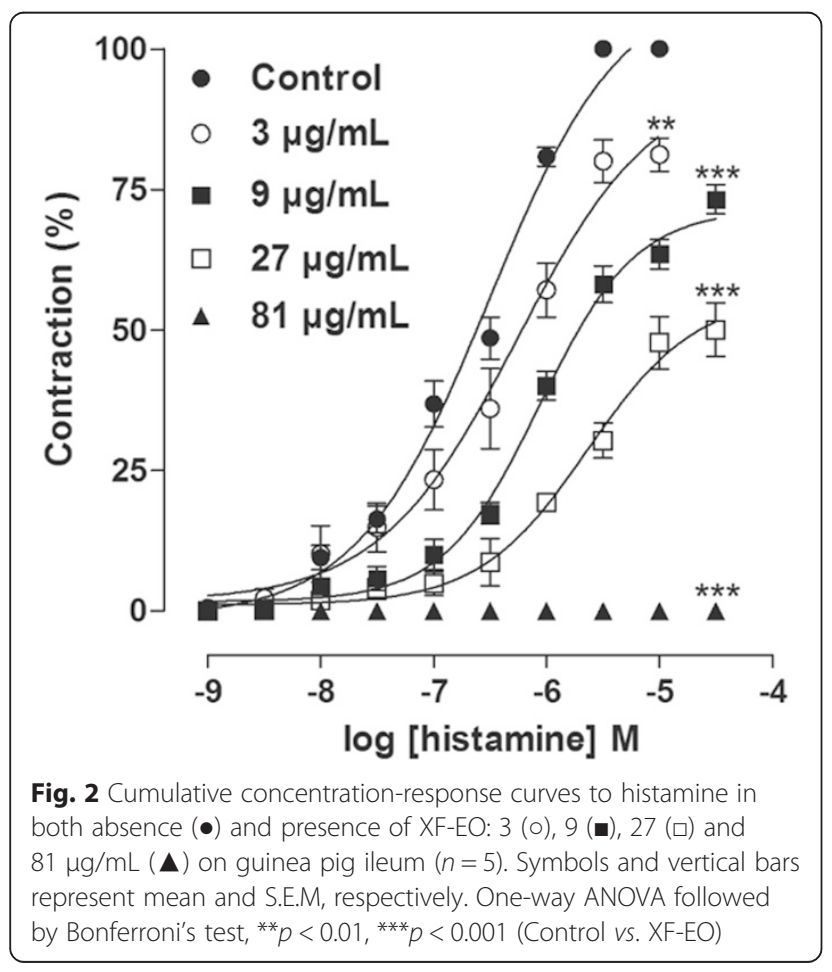

(control) to $3.8 \pm 0.9,7.3 \pm 0.1 \times 10^{-7} \mathrm{M}$ and $1.5 \pm 0.1 \times$ $10^{-6} \mathrm{M}$ (Fig. 2).

Effect of XF-EO on $\mathrm{KCl}$-induced tonic contraction or histamine-induced tonic contractions in both absence and presence of non-selective potassium channel blocker

XF-EO $(0.3-729$ or $0.3-81 \mu \mathrm{g} / \mathrm{mL}, n=5)$ showed a concentration-dependent spasmolytic effect on ileum pre-contracted with $\mathrm{KCl}\left(\mathrm{EC}_{50}=13.9 \pm 1.6 \mu \mathrm{g} / \mathrm{mL}\right)$ or histamine $\left(\mathrm{EC}_{50}=7.1 \pm 0.6 \mu \mathrm{g} / \mathrm{mL}\right)$ (Fig. 3a). XF-EO relaxant effect was partially reversed $2 \mathrm{~h}$ after its removal from organ baths in $62.4 \pm 4.2$ and $77.8 \pm 2.5 \%$, respectively (data not shown).

XF-EO spasmolytic effect on histamine-induced tonic contraction did not modify statistically in the presence of $\mathrm{CsCl}\left(\mathrm{EC}_{50}=7.7 \pm 1.2 \mu \mathrm{g} / \mathrm{mL}, n=3\right)$ (Fig. 3b).

\section{Effect of XF-EO on $\mathrm{Ca}^{2+}$ influx}

XF-EO (9-81 $\mu \mathrm{g} / \mathrm{mL}, n=5)$ concentration-dependently inhibited $\mathrm{Ca}^{2+}$-induced cumulative contractions in a depolarizing medium nominally without $\mathrm{Ca}^{2+}$ (Fig. 4a). $\mathrm{CaCl}_{2}$ cumulative concentration-response curve was non-parallelly shifted to the right and $E_{\max }$ reduced from $100 \%$ (control) to $93.2 \pm 3.6,77.7 \pm 4.0,26.3 \pm$ 2.2 and $10.7 \pm 2.6 \%$. The $\mathrm{EC}_{50}$ was attenuated from $0.7 \pm 0.1 \times 10^{-3} \mathrm{M}$ (control) to $1.0 \pm 0.1,4.0 \pm 0.2$ and $9.5 \pm 1.3 \times 10^{-3} \mathrm{M}$ (Fig. 5).

XF-EO $(0.1-729 \mu \mathrm{g} / \mathrm{mL}, n=5)$ showed a concentrationdependent spasmolytic effect on ileum pre-contracted with S-(-)-Bay K8644, a selective $\mathrm{Ca}_{\mathrm{V}} 1$ agonist (Fig. 4b). $\mathrm{XF}-\mathrm{EO}$ was 5 fold more potent in relaxing the ileum precontracted with $\mathrm{KCl}\left(\mathrm{EC}_{50}=13.9 \pm 1.6 \mu \mathrm{g} / \mathrm{mL}\right)$ than with S-(-)-Bay K8644 $\left(\mathrm{EC}_{50}=74.5 \pm 8.2 \mu \mathrm{g} / \mathrm{mL}\right)$. 

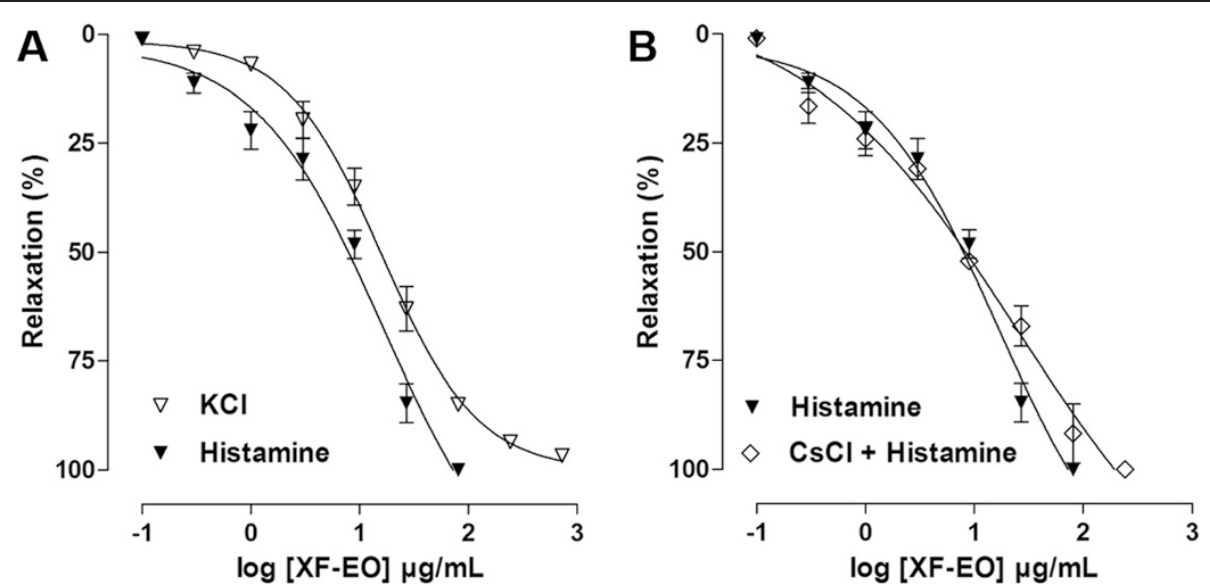

Fig. 3 Effect of XF-EO on tonic contractions induced by $\mathrm{KCl}(40 \mathrm{mM})(\nabla)$ or histamine $\left(10^{-6} \mathrm{M}\right)$ in both absence $(\boldsymbol{\nabla})(\mathbf{a})$ and presence $(\diamond)$ of $\mathrm{CsCl}$ $(5 \mathrm{mM})(\mathbf{b})$ on guinea pig ileum $(n=3-5)$. Symbols and vertical bars represent mean and S.E.M., respectively

Effect of XF-EO on myocytes from ileum longitudinal layer

Interference of XF-EO in the viability of ileum myocytes XF-EO $(81 \mu \mathrm{g} / \mathrm{mL}, n=3)$ did not induced cellular death on ileum myocytes during $2 \mathrm{~h}$ of exposure (Fig. 5).

\section{Effect of XF-EO on cytosolic calcium concentration of ileum myocytes}

Histamine $\left(10^{-6} \mathrm{M}\right)$ induced an increase on Fluo-4associated fluorescence intensity, remaining stable throughout the stimulation period (220 s) (Figs. 6a and 7). After the stimulation with histamine, at $110 \mathrm{~s}$, XF-EO (81 $\mu \mathrm{g} / \mathrm{mL})$ addition induced a reduction on Fluo-4associated fluorescence intensity of cells, sustaining this reduction $(97.0 \pm 3.0 \%, n=3)$ throughout the period of exposure to the essential oil (Figs. 6b and 7). In the same way, verapamil $\left(10^{-6} \mathrm{M}\right)$, a $\mathrm{Ca}_{\mathrm{V}} 1$ blocker, reduced the $\left[\mathrm{Ca}^{2+}\right]_{\mathrm{c}}$ in the initial $10 \mathrm{~s}$, staying reduced $(65.5 \pm$ $4.1 \%, n=3$ ) throughout the observation period, showing a significant Fluo-4-associated fluorescence intensity decrease (Figs. 6c and 7). The Fluo-4-associated fluorescence decrease showed during the initial $20 \mathrm{~s}$ of exposure of the cells to the drugs is caused for the presence of HBSS, as can be demonstrated by a biphasical elevation of the Fluo-4-associated fluorescence intensity after histamine addition, falling slightly and remaining stable throughout the observation period (Figs. 6d and 7).

\section{Discussion}

This study demonstrated for the first time that the essential oil from leaves of Xylopia frutescens Aubl. (XFEO) shows spasmolytic action on guinea pig ileum. Moreover, the most significant finding concerns the
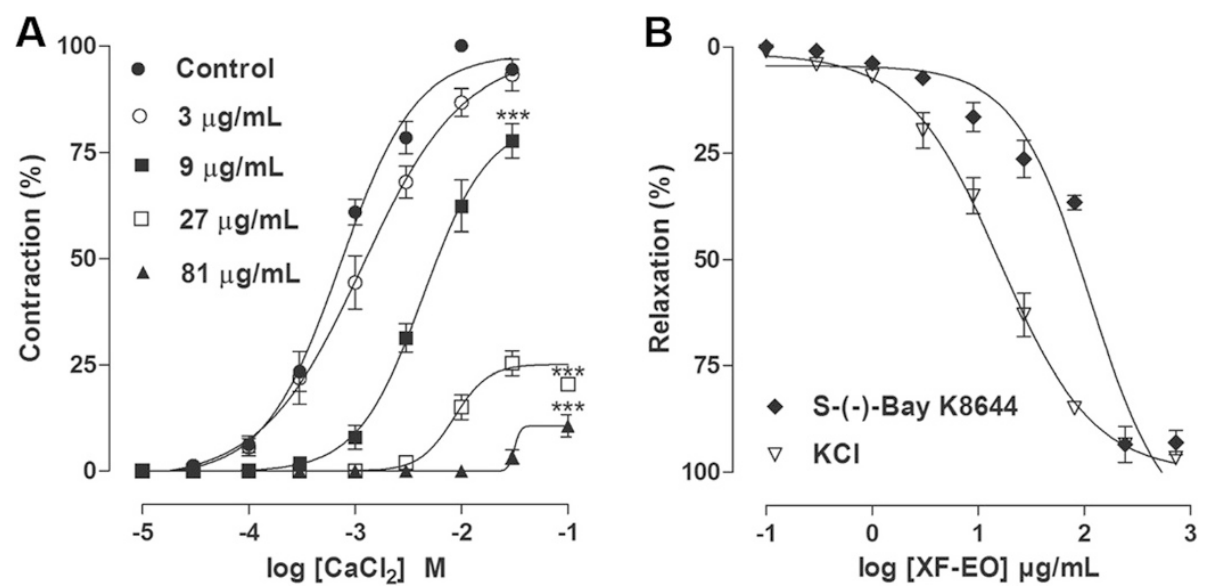

Fig. 4 Effect of XF-EO on cumulative curves to $\mathrm{CaCl}_{2}$ in absence $(\bullet)$ or presence of $3(0), 9(\mathbf{\bullet}), 27(\square)$ and $81 \mu \mathrm{g} / \mathrm{mL}(\mathbf{\Delta})(\mathbf{a})$ or $\mathrm{KCl}(40 \mathrm{mM})(\nabla)$ or S-(-)-Bay K8644 $\left(3 \times 10^{-7} \mathrm{M}\right)(\bullet)$ tonic contraction $(\mathbf{b})$ on guinea pig ileum $(n=5)$. Symbols and vertical bars represent mean and S.E.M, respectively. One-way ANOVA followed by Bonferroni's test, ${ }^{* * *} p<0.001$ (Control vs. XF-EO) 


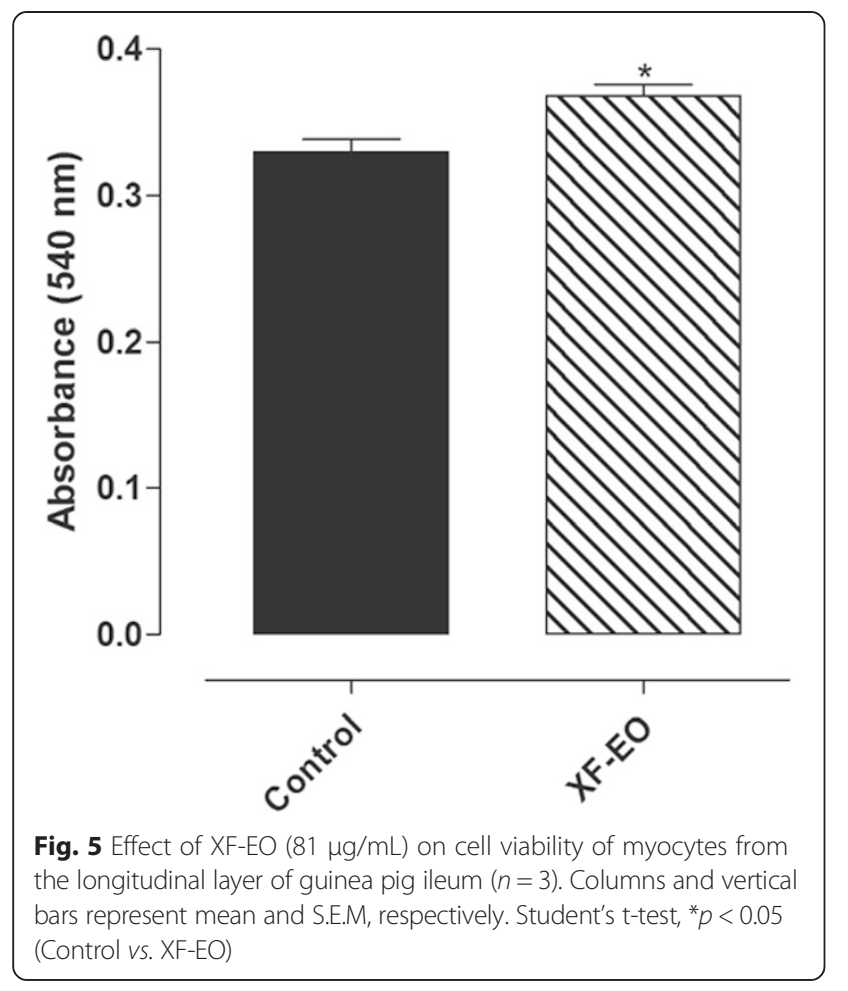

characterization of relaxant action mechanism, which includes histaminergic receptor antagonism and possible blockade of $\mathrm{Ca}_{\mathrm{v}} 1$ which reduces cytosolic $\mathrm{Ca}^{2+}$ concentration $\left(\left[\mathrm{Ca}^{2+}\right]_{\mathrm{c}}\right)$ leading to smooth muscle relaxation.

Pharmacologic diarrhea therapy include antimotility, spasmolytic, antisecretory, adsorbents, probiotics, antiinfective and miscellaneous agents like $\alpha_{2}$-adrenergic receptor antagonist, $\mathrm{Ca}^{2+}$ channel blockers and calmodulin inhibitors [30, 31]. Spasmolytic agents can act by blocking specific receptors present in smooth muscles, such as muscarinic cholinergic or histamine receptors, in a non-specific way, reducing the contractile response from several patterns of stimuli [32].

In the investigation of this study, we detected the presence of spathulenol (1.37\%), considered a marker of essential oils obtained from Xylopia genus [33] on the XF-EO. In addition, this essential oil presented a higher percentage of mono- and sesquiterpenes (Table 1). In the pharmacological approach, we found that XF-EO inhibited both CCh- and histamine-induced contractions in a concentration-dependent manner, being more potent in antagonized the histamine-induced contractions (Fig. 1). These data indicate that the essential oil might be acting as a direct antagonist of histamine receptors to promote its spasmolytic effect.

Thus, we investigated the role of histamine receptors using cumulative concentration-response curves to this agonist. XF-EO showed a noncompetitive pharmacologic profile, shifting the histamine cumulative curve nonparallelly to the right with $\mathrm{E}_{\max }$ reduction (Fig. 2), so the competitive antagonism on histaminergic receptors was refuted. Inhibition of histamine contractile response in XF-EO presence have no shown a limiting value, suggesting a noncompetitive pseudo-irreversible antagonism of $\mathrm{H} 1$ receptors. In this particular kind of antagonism, the drug dissociation rate occurs slowly, presenting a prolonged action [34].

Smooth muscle presents a biphasic contraction attributed to a dual source of $\mathrm{Ca}^{2+}[35,36]$. Particularly, on ileum contraction, the first phase exhibits a fast and transient contraction (phasic component) followed by a long-lasting second phase characterized by the maintained contraction (tonic component) [37, 38]. The removal of extracellular $\mathrm{Ca}^{2+}$ prevents contractile responses induced by depolarizing agents (electromechanical coupling), such as $\mathrm{KCl}$, or by agonists of mixed coupling (pharmacomechanical and electromechanical), such as histamine, in few seconds, suggesting that the intracellular $\mathrm{Ca}^{2+}$ do not contribute significantly to the tension level [39].

Since the mechanisms involved in tonic contraction maintenance are different from the phasic contraction on guinea-pig ileum [35], we decided to investigate if the essential oil promotes ileum relaxation when precontracted with $\mathrm{KCl}$ or histamine. XF-EO relaxed this organ pre-contracted with both contractile agents in a concentration-dependent manner, being 2 folds more potent in relaxing the ileum pre-contracted with histamine (Fig. 3a). Partial reverse effect observed can be justified by a noncompetitive pseudo-irreversible antagonism promoted by the essential oil.

Considering that $\mathrm{K}^{+}$channel openers reduce contractile response evoked by low $\mathrm{K}^{+}$concentration and presents potency decreased at high $\mathrm{K}^{+}$concentration [40], another relevant hypothesis is that the essential oil can acts as a $\mathrm{K}^{+}$channel positive modulator. Therefore, in order to verify this hypothesis, XF-EO relaxant effect was assayed in the presence of $\mathrm{CsCl}$, a non-selective $\mathrm{K}^{+}$ channel blocker. The presence of $\mathrm{CsCl}$ did not alter the essential oil spasmolytic potency (Fig. 3b), suggesting that these channels are not involved in XF-EO action mechanism.

Ileal contractile responses are highly dependent on an increase in free cytoplasmic $\mathrm{Ca}^{2+}$. The $\left[\mathrm{Ca}^{2+}\right]_{\mathrm{c}}$ increase is due to either influx via $\mathrm{Ca}_{V}$ or release from intracellular stores [41]. To test if the essential oil is blocking $\mathrm{Ca}^{2+}$ influx through $\mathrm{Ca}_{V}$ to promote the spasmolytic action, $\mathrm{CaCl}_{2}$ cumulative contractions were induced in a depolarizing medium nominally without $\mathrm{Ca}^{2+}$. This protocol is based on the fact that contraction will be obtained almost exclusively by $\mathrm{Ca}^{2+}$ from extracellular medium, since depolarization promoted by elevated extracellular $\mathrm{K}^{+}$concentrations leads to $\mathrm{Ca}_{\mathrm{V}}$ opening [42]. XF-EO 


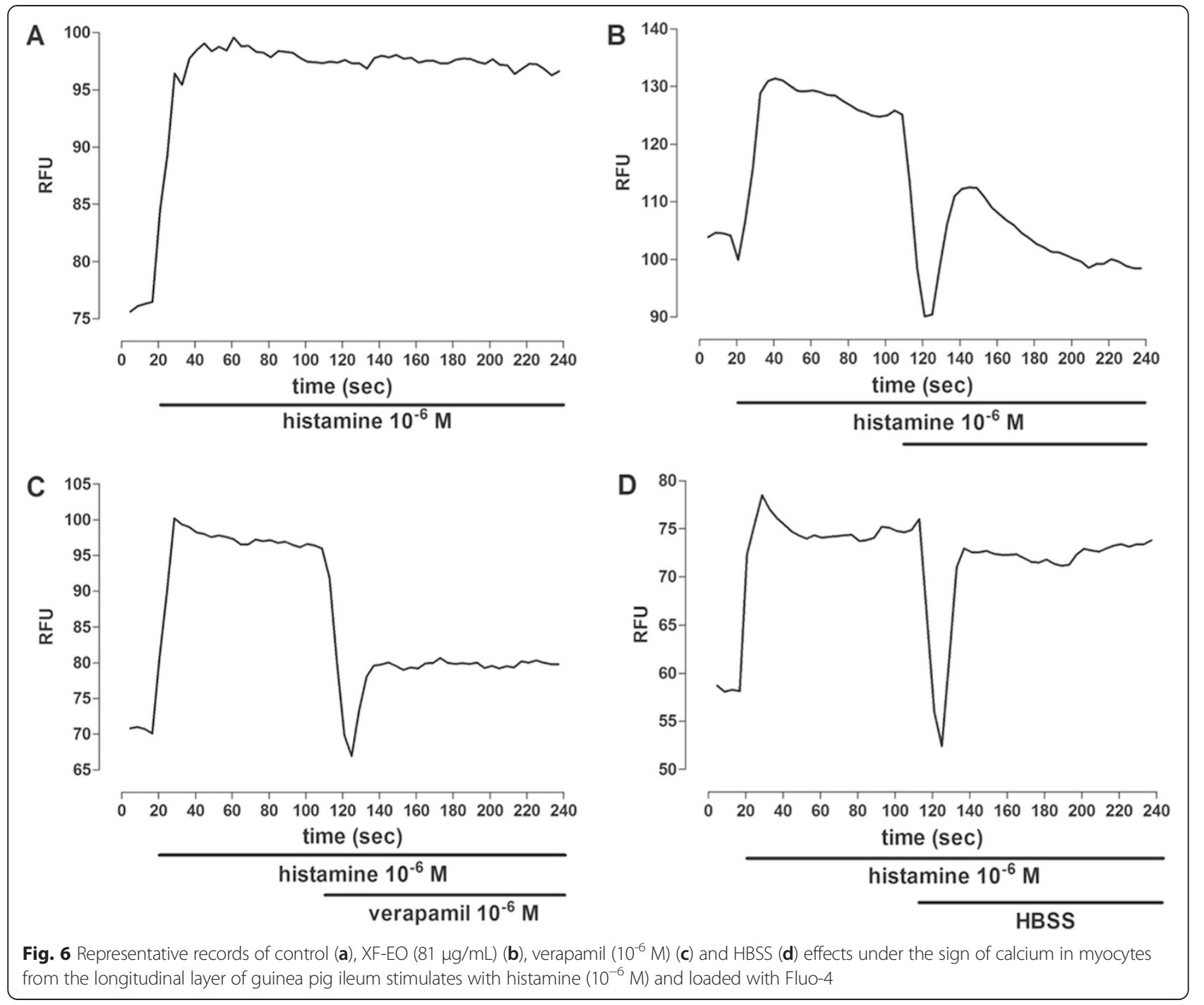

inhibited $\mathrm{CaCl}_{2}$-induced contractions, shifting the curves to the right and reducing $\mathrm{E}_{\max }$ (Fig. 4a), reinforcing the hypothesis of $\mathrm{Ca}^{2+}$ influx blockade.

$\mathrm{Ca}_{\mathrm{V}}$ are composed by 4 subunits $(2 \alpha, 1 \beta$ and $1 \gamma)$ where $\alpha 1$ forms the pore that leads to $\mathrm{Ca}^{2+}$ influx [43, 44] and are subdivided as $\mathrm{Ca}_{\mathrm{V}} 1.1, \mathrm{Ca}_{\mathrm{V}} 1.2, \mathrm{Ca}_{\mathrm{V}} 1.3$ and $\mathrm{Ca}_{\mathrm{V}} 1.4$, sensitive to dihydropyridine and high voltage [45]. In smooth muscle, $\mathrm{Ca}_{v} 1$ are the main responsible to $\mathrm{Ca}^{2+}$ influx. Thus, the next step was to confirm and identify the $\mathrm{Ca}_{V}$ subtype involved on XF-EO spasmolytic action. Therefore, tonic contractions were obtained with S(-)-Bay K8644, a specific dihydropyridine derivative agonist for $\mathrm{Ca}_{v} 1$ that binds directly with $\alpha 1$ subunit to open these channels, but not by depolarization [46]. XF-EO relaxed the ileum pre-contracted with $\mathrm{KCl}$ than $\mathrm{S}-(-)$-Bay K8644 (Fig. 4b) suggesting the inhibition of $\mathrm{Ca}^{2+}$ influx through $\mathrm{Ca}_{\mathrm{v}} 1$. Meanwhile, the essential oil was more potent in relaxing the ileum pre-contracted with $\mathrm{KCl}$ than S-(-)-Bay K8644 (Fig. 4b), suggesting that the $\mathrm{Ca}^{2+}$ influx blockade through $\mathrm{Ca}_{\mathrm{v}} 1$ is implicated in the essential oil action mechanism, however other mechanisms seems to be involved in these spasmolytic action, as the inhibited of $\mathrm{Ca}^{2+}$ release from intracellular stores [47].

The $\left[\mathrm{Ca}^{2+}\right]_{\mathrm{c}}$ decrease is required to promote relaxation on smooth muscle $[48,49]$. Nowadays, techniques that use fluorescent indicators allow us to measure the cytosolic $\mathrm{Ca}^{2+}$ concentration in several models of smooth muscles [50]. Heretofore, the XF-EO spasmolytic action mechanism theoretically reduces $\left[\mathrm{Ca}^{2+}\right]_{\mathrm{c}}$ availability possible due to $\mathrm{Ca}_{V} 1$ blockade, but no evidence of this has been shown. Thus, we aimed to provide evidence of $\left[\mathrm{Ca}^{2}\right.$ $\left.{ }^{+}\right]_{\mathrm{c}}$ reduction by the essential oil in myocytes isolated from ileum longitudinal layer and, so, better characterize its action mechanism. Initially, cell viability was evaluated using the XF-EO maximal concentration used in functional level. In $2 \mathrm{~h}$ of XF-EO exposure to the cells was not observed cell death (Fig. 5), this data shows that spasmolytic action is not due to cell death. This way, 


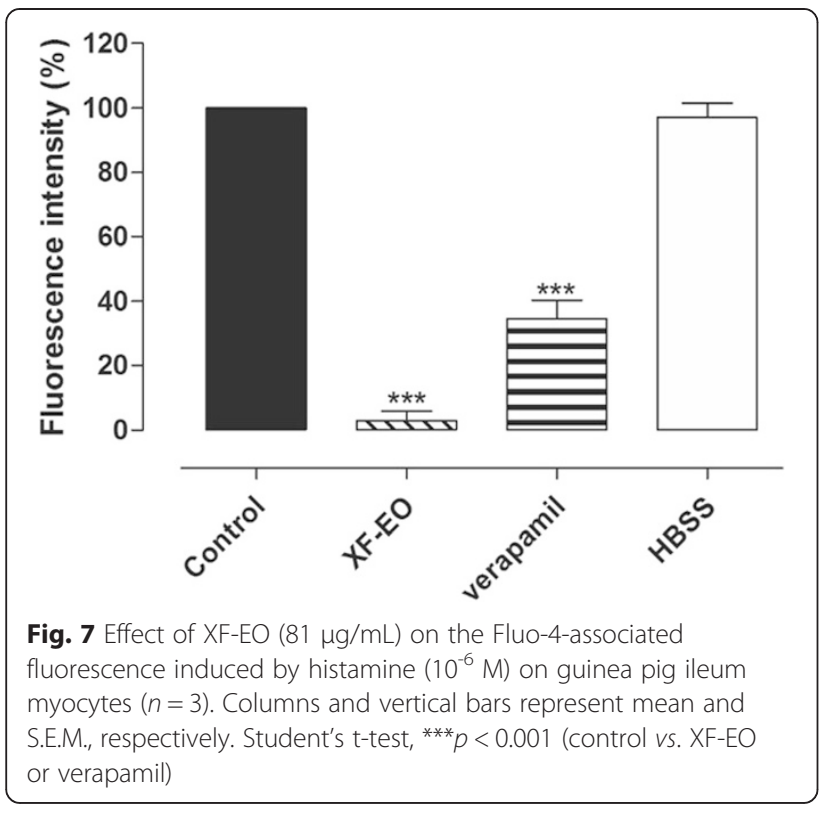

Fluo-4, a fluorescent indicator of $\mathrm{Ca}^{2+}$, was added to the preparations containing ileum myocytes and the resultant Fluo-4-associated fluorescence was quantified in XF-EO presence. The essential oil reduced the great Fluo-4associated fluorescence emitted in histamine presence, which indicates $\left[\mathrm{Ca}^{2+}\right]_{\mathrm{c}}$ reduction of $97 \%$ approximately (Figs. 6 and 7). This reduction is consistent with what was observed in functional level, where maximum relaxation (100 \%) was obtained in the $81 \mu \mathrm{g} / \mathrm{mL}$ concentration (Fig. 3a). These results in cellular experiments support our findings in functional level and evidence that XF-EO reduce $\left[\mathrm{Ca}^{2+}\right]_{\mathrm{c}}$ to play its spasmolytic role.

\section{Conclusion}

In conclusion, the spasmolytic action of the essential oil from Xylopia frutescens Aubl. on guinea pig ileum involves the histaminergic receptor antagonism and possible $\mathrm{Ca}_{\mathrm{V}} 1$ blockade. In addition, it is now established that, in cellular experiments, XF-EO decrease $\left[\mathrm{Ca}^{2+}\right]_{\mathrm{c}}$ to promote the spasmolytic action observed in tissue experiments. Further complementary studies on this essential oil in vivo protocol are needed to pursue the search for a potential antidiarrheal agent.

\section{Abbreviations}

XF-EO: Essential oil from Xylopia frutescens Aubl..

\section{Competing interests}

The authors declare that they have no competing interests.

\section{Authors' contributions}

SILL is the author who mainly contributed to this research, performing literature search, pharmacological experiments, analysis of the data and writing the manuscript. ALCC, VLHC and SMCC were involved in acquisition, interpretation and analysis of functional pharmacological experiments. CACC was involved in acquisition, interpretation and analysis of cellular experiments under supervision of the PhD PGEJ. CVCO performed the phytochemical isolation of the essential oil studied under supervision of the PhD TJF. The PhDs CFA and SBA were involved in design, interpretation of the data and review of the manuscript. All authors read and approved the final manuscript.

\section{Acknowledgements}

The authors thank CAPES, CNPq and FAPESQ-PB for financial support. UNIFESP for the experimental support, Vera Lúcia Silva Rigoni, Marcus Vinicius Buri, José Crispim Duarte and Luís C. Silva for providing technical assistance.

\section{Author details}

${ }^{1}$ Centro de Ciências da Saúde/Universidade Federal da Paraíba, João Pessoa, Paraíba, Brazil. ${ }^{2}$ Instituto de Ciências Biológicas e da Saúde/Universidade Federal de Alagoas, Maceió, Alagoas, Brazil. ${ }^{3}$ Centro de Ciências Exatas e da Natureza/Universidade Federal da Paraíba, João Pessoa, Paraíba, Brazil. ${ }^{4}$ Instituto de Pesquisa em Fármacos e Medicamentos/Universidade Federal da Paraíba, João Pessoa, Paraíba, Brazil. " Instituto Nacional de Farmacologia/ Universidade Federal de São Paulo, São Paulo, São Paulo, Brazil. ' Universidade Federal da Paraíba, Centro de Ciências da Saúde/Pós-Graduação em Produtos Naturais e Sintéticos Bioativos/Laboratório de Farmacologia Funcional Prof. George Thomas, Cidade, Universitária, P.O. Box 500958051-970 João Pessoa, Paraíba, Brazil.

Received: 26 March 2015 Accepted: 3 September 2015

Published online: 16 September 2015

\section{References}

1. Shafi A, Farooq U, Akram K, Jaskani M, Siddique F, Tanveer A. Antidiarrheal effect of food fermented by various strains of Lactobacillus. Compr Rev Food Sci F. 2014;13:229-39.

2. World Health Organization. World Health Organization Diarrhea Guidelines. 2014 http://www.who.int/topics/diarrhoea/en. Accessed 02 April 2014.

3. Ventura-Martínez R, Rivero-Osorno O, Gómez C, González-Trujano ME. Spasmolytic activity of Rosmarinus officinalis L. involves calcium channels in the guinea pig ileum. J Ethnopharmacol. 2011;137:1528-32.

4. Costa LCB, Rocha EA, Silva LAM, Jardim JG, Silva DC, Gaião LO, et al. Levantamento preliminar das espécies vegetais com potencial econômico no Parque Municipal da Boa Esperança, Ilhéus, Bahia, Brasil. Acta Farm Bonaer. 2006;25:184-91.

5. Duke JA, Vasquez-Martinez R. Amazonian ethnobotanical dictionary. 2nd ed. Boca Raton, Florida: CRC Press; 1994.

6. Takahashi JA, Boaventura MAD, Bayma JC, Oliveira AB. Frutoic acid, a dimeric kaurane diterpene from Xylopia frutescens. Phytochem. 1995;40:607-9.

7. Braga FC, Wagner $H$, Lombardi JA, Oliveira AB. Screening Brazilian plant species for in vitro inhibition of 5-lipoxygenase. Phytomedicine. 2000;6:447-52.

8. Block LC, Santos ARS, Souza MM, Scheidt C, Yunes RA, Santos MA, et al. Chemical and pharmacological examination of antinociceptive constituents of Wedelia paludosa. J Ethnopharmacol. 1998;61:85-9.

9. Somova LI, Shode FO, Moodley K, Govender Y. Cardiovascular and diuretic activity of kaurene derivatives of Xylopia aethiopica and Alepidea amatymbica. J Ethnopharmacol. 2001;77:165-74.

10. Matsuse IT, Lim YA, Hattori M, Correa M, Gupta MP. A search for anti-viral properties in Panamanian medicinal plants. The effects on HIV and its essential enzymes. J Ethnopharmacol. 1999:64:15-22.

11. Lima EO, Gompertz OF, Paulo MQ, Giesbrecht AM. Atividade antifúngica in vitro de óleo essenciais frente a isolados clínicos de dermatófitos. Rev Microbiol. 1992;23:235-68.

12. Silva TB, Menezes LRA, Sampaio MFC, Meira CS, Guimarães ET, Soares MBP, et al. Chemical composition and anti-trypanossoma cruzi activity of essential oils obtained from leaves of Xylopia frutescens and X. laevigata (Annonaceae). Nat Prod Commun. 2013;8:403-6.

13. Ferraz RP, Cardoso GM, Silva TB, Fontes JE, Prata AP, Carvalho AA, et al. Antitumor properties of the leaf essential oil of Xylopia frutescens Aubl. (Annonaceae). Food Chem. 2013;141:196-200.

14. Correia ACC. Estudo Comparativo da atividade espasmolítica de óleos essenciais de espécies de Annonaceae. In: Rollinia leptopetala R. E. Fries, Xylopia langsdorfiana A. St.-Hil. \& Tul. e Xylopia frutescens Aubl. João Pessoa: Universidade Federal da Paraíba; 2013. 
15. Adams RP. Identification of essential oil components by gas chromatography/mass spectrometry. Carol Stream, USA: Allured Publishing Corporation; 2007.

16. National Institute of Standards and Technology (NIST). Mass Spectral Library. Gaithersburg, USA: The NIST Mass Spectrometry Data Center; 2005.

17. Sherwin CM, Christiansen SB, Duncan IJH, Erhard HW, Lay DC, Mench JA, et al. Guidelines for the ethical use of animals in applied animal behaviour research. Appl Anim Behav Sci. 2003;81:291-305.

18. Sun YD, Benishin CG. $\mathrm{K}^{+}$channel openers relax longitudinal muscle of guinea-pig ileum. Eur J Pharmacol. 1994;271:453-9.

19. Claro S, Kanashiro CA, Oshiro MEM, Ferreira AT, Khalil RA. a-and $\varepsilon$-protein kinase $C$ activity during smooth muscle apoptosis in response to $\gamma$-radiation. J Pharmacol Exp Ther. 2007;322:964-72.

20. Daniel EE, Kwan CY, Janssen L. Pharmacological techniques for the in vitro study of intestinal smooth muscle. J Pharmacol Toxicol. 2001;45:141-59.

21. Dunne A. Comparison of individual and cumulative dose-response curves [proceedings]. Br J Pharmacol. 1979;67:491-2.

22. Cecchi X, Wolff D, Alvarez O, Latorre R. Mechanisms of $\mathrm{Cs}^{+}$blockade in a $\mathrm{Ca}^{2+}$-activated $\mathrm{K}^{+}$channel from smooth muscle. Biophys J. 1987;52:707-16.

23. Knot HT, Brayden EJ, Nelson MT. Calcium channels and potassium channels. In: Bárány M, editor. Biochemistry of smooth muscle contraction. San Diego: Academic; 1996. p. 203-19.

24. Van Rossum JM. Cumulative dose-response curves. Arch Int Pharmacodyn Ther. 1963;143:299-330.

25. Usowicz MM, Gigg M, Jones LM, Cheung CW, Hartley SA. Allosteric interactions at L-type calcium channels between FPL 64176 and the enantiomers of the dihydropyridine Bay K 8644. J Pharmacol Exp Ther. 1995;275:638-45.

26. Ferrante J, Luchowski E, Rutledge A, Triggle DJ. Binding of a 1,4-dihydropyridine calcium channel activator, S-(-)-Bay K8644, to cardiac preparations. Biochem Biophys Res Commun. 1989;158:149-54.

27. Denizot F, Lang R. Rapid colorimetric assay for cell growth and survival, modifications to the tetrazolium dye procedure giving improved sensitivity and reliability. J Immunol Methods. 1986;89:271-7.

28. Paredes RM, Etzler JC, Watts LT, Zheng W, Lechleiter JD. Chemical calcium indicators. Methods. 2008;46:143-51.

29. Neubig RR, Spedding M, Kenakin T, Christopoulos A. International union of pharmacology committee on receptor nomenclature and drug classification. XXXVIII. Update on terms and symbols in quantitative pharmacology. Pharmacol Rev. 2003;55:597-606.

30. Pasricha PJ. Treatment of disorders of bowel motility and water flux; antiemetics; agents used in biliary and pancreatic disease. In: Brunton LL, Lazo JS, Parker KL, editors. Goodman and Gilman's the pharmacological basis of therapeutics. USA: McGraw-Hill; 2006. p. 983-1019.

31. Mims BC, Curry Jr CE. Constipation, diarrhea, and irritable bowel syndrome. In: Brown M, Malley J, Pancotti R, Brown RY, editors. Pharmacotherapy principles and practice. USA: McGraw-Hill; 2008. p. 307-21.

32. Maia GS, Andrade EHA, Silva ACM, Oliveira J, Carreira LMN, Araújo JS. Leaf volatile oils from Brazilian Xylopia species. Flavor Frag J. 2005;20:474-7.

33. Madeira SVF, Matos FJA, Leal-Cardoso JH, Criddle DN. Relaxant effects of the essential oil of Ocimum gratissimum on isolated ileum of the guinea pig. J Ethnopharmacol. 2002;81:1-4.

34. May LT, Leach K, Sexton PM, Christopoulos A. Allosteric modulation of G protein-coupled receptors. Annu Rev Pharmacol Toxicol. 2007;47:1-51.

35. Abdel-Latif AA. Calcium mobilizing receptors, polyphospholinositides, generation of second messengers and contraction in mammalian smooth muscle: historical perspectives and current status. Life Sci. 1989;45:757-86.

36. Kobayashi S, Kitazawa T, Somlyo AV, Somlyo AP. Citosolic heparin inhibits muscarinic and a-adrenergic $\mathrm{Ca}^{2+}$-release in smooth muscle: physiological role of inositol 1,4,5-trisphosphate in pharmacomechanical coupling. J Biol Chem. 1989;264:17997-8004.

37. Horie S, Tsurumaki Y, Someya A, Hirabayashi T, Saito T, Okuma Y, et al. Involvement of cyclooxygenase-dependent pathway in contraction of isolated ileum by urotensin II. Peptides. 2005;26:323-9.

38. Tanahashi Y, Unno T, Matsuyama H, Ishii T, Yamada M, Wess J, et al. Multiple muscarinic pathways mediate the suppression of voltage-gated $\mathrm{Ca}^{2+}$ channels in mouse intestinal smooth muscle cells. Br J Pharmacol. 2009;158:1874-83.

39. Nouailhetas VLA, Shimuta SI, Paiva ACM, Paiva TB. Calcium and sodium dependence of the biphasic response of the guinea-pig ileum agonists. Eur J Pharmacol. 1985;116:41-7.
40. Yuan YM, Xu DY, Hu GY. Pinacidil suppression on 5-HT3 receptor-mediated contraction of guinea pig ileum in vitro. Acta Pharmacol Sin. 1998;19:31-5.

41. Karaki H, Mitsui-Saito M, Amano K, Harada K, Miyamoto S, Nakazawa H, et al. Calcium movements, distribution, and functions in smooth muscle. Pharmacol Rev. 1997;49:157-230.

42. Rembold CM. Regulation of contraction and relaxation in arterial smooth muscle. Hypertension. 1992;20:129-37.

43. Kuriyama H, Kitamura K, Nabata H. Pharmacological and physiological significance of ion channels and factors that modulate them in vascular tissues. Pharmacol Rev. 1995;47:387-573.

44. Catterall WA. Voltage-gated calcium channels. Cold Spring Harb Perspect Biol. 2011;11:1-24.

45. Alexander SPH, Mathie A, Peters JA. Guide to Receptors and Channels (GRAC). Br J Pharmacol. 2008;2:153.

46. Spedding M, Paoletti R. Classification of calcium channels and the sites of action of drugs modifying channel function. Pharmacol Rev. 1992;44:363-76.

47. Murthy KS. Signaling for contraction and relaxation in smooth muscle of the gut. Annu Rev Physiol. 2006;68:345-74.

48. Somlyo AP, Somlyo AV. Signal transduction and regulation in smooth muscle. Nature. 1994;372:231-6.

49. Webb RC. Smooth muscle contraction and relaxation. Adv Physiol Ed. 2003;27:201-6

50. Wray S, Kupittayanant S, Shmigol A, Smith RD, Burdyga TV. The physiological basis of uterine contractility: a short review. Exp Physiol. 2001;86:239-46.

\section{Submit your next manuscript to BioMed Central and take full advantage of:}

- Convenient online submission

- Thorough peer review

- No space constraints or color figure charges

- Immediate publication on acceptance

- Inclusion in PubMed, CAS, Scopus and Google Scholar

- Research which is freely available for redistribution 